\title{
Lecturer Turnover and Its Effect on the Performance of Students: A Case Study of Accra Polytechnic
}

\author{
H. Hammond ${ }^{1}$, F. Kutsanedzie ${ }^{2}$ \\ ${ }^{1}$ Finance Department, Accra Polytechnic, Accra, Ghana \\ ${ }^{2}$ Department of Research and Innovation, Accra Polytechnic, Accra, Ghana \\ Email: fkutsanedzie@apoly.edu.gh
}

Received 6 November 2015; accepted 21 November 2015; published 25 November 2015

Copyright (C) 2015 by authors and OALib.

This work is licensed under the Creative Commons Attribution International License (CC BY). http://creativecommons.org/licenses/by/4.0/

(c) (i) Open Access

\begin{abstract}
Academic performance in institution of higher learning generally is thought to be falling in Ghana. One of the reasons that have been ascribed to the declining performance has been the high turnover rate among lecturers in these higher educational institutions. This study was therefore undertaken in Accra Polytechnic to determine effects of lecturer turnover on students' performance. The study utilized a descriptive survey research approach, in which a well structured questionnaire was designed, comprising close ended questions was administered by randomly to 100 students in Accra Polytechnic to obtain the primary data, and using secondary data on lecturers and student information obtained from Accra Polytechnic Administration. Data were collected from the respondents, collated and summarized using statistical tools such as tables and figures. The study revealed that lecturer turnover adversely affected students' preparation towards examination. 90 per cent of the students sampled stated that when lecturers resigned in the middle of the semester their preparation towards exams was adversely affected. The study found that turnover did not always result in the decline of students' performance. It is therefore recommended that to effectively deal with turnover of lecturers when they occur, educational institutions must always find very efficient lecturers as replacement so the performance of the students is not adversely affected.
\end{abstract}

\section{Keywords}

Turnover, Employee, Performance, Motivation, Commitment

Subject Areas: Sociology

How to cite this paper: Hammond, H. and Kutsanedzie, F. (2015) Lecturer Turnover and Its Effect on the Performance of Students: A Case Study of Accra Polytechnic. Open Access Library Journal, 2: e1933.

http://dx.doi.org/10.4236/oalib.1101933 


\section{Introduction}

\subsection{Background of the Study}

As globalisation catches up with countries and its attendant competition, organisations need to be competitive, staying competitive means devising strategies to outwit the competitors. [1] in their study states that with the heightened competition as a result of globalization, it beholds on organisations to produce tangible goods and services which are based on strategies from highly skilled personnel. Employees therefore are crucial to the organisation and an intangible which cannot easily be replicated. Although workforce stability is a powerful competitive strategy currently valued by organisations, it is almost impossible and unrealistic for agencies to maintain zero turnover [2]. With the labour force becoming increasingly mobile, fewer employees are staying with one organisation throughout their careers [2].

Today's business environment has become very competitive thus making skilled labour the major differentiating factor for most organisations. Organisations - both public and private-rely on the expertise of their employees in order to compete favourably and indeed gain competitive advantage in the international market. However, recent studies have shown that retention of highly skilled employees has become a difficult task for managers as this category of employees are being attracted by more than one organisation at a time with various kinds of incentives [3]. [4] has shown that labour, on average switches employers every six years. This situation demands that management identifies the reason/s for this frequent change of employment as this retards performance of organisations. Employee turnover has become an important area of research from both a theoretical and practical standpoint. It is important from a theoretical perspective, in understanding how the underlying causes of turnover can provide insights into how to control the phenomenon.

The current study seeks to investigate whether labour turnover is a good predictor of organisations' performance using Accra Polytechnic as a case study.

\subsection{Statement of Problem}

Employee turnover is now an issue that has come to stay with organisations, almost every organisation has employee turnover problems. [2] states that work place stability is a powerful tool in this competitive business environment; employees are increasingly becoming mobile and employee hardly stays with a particular employer for a long period. [5] states that, some level of turnover is necessary and desirable, after a lot of investment has gone into training and developing employees, it becomes costly for the organisation when the rate of turnover is high.

Accra polytechnic has had its own share of labour turnover problems. What makes it worse for Accra Polytechnic is that after sponsoring its teaching staff for further studies, other organisations poach them. This problem has persisted for several years hence the need to conduct this study to determine the effect this has on the performance of Accra Polytechnic. Organisations invest a lot in their employees in terms of induction and training, developing, maintaining and retaining them in their organisation. Therefore, managers at all costs must minimize employee's turnover so that their investments in employees will translate to improved performance.

\subsection{Objectives of the Study}

The main objective of the study is to find out whether lecturer turnover affects students' performance in Accra Polytechnic.

\section{Methodology}

\subsection{Sampling and Sampling Procedure}

Both stratified and random sampling technique was employed in selecting one hundred (100) students of Accra Polytechnic for the study. The students were selected from ten (10) departments. Also the stratified sampling technique was used to select ten (10) students from their each department comprising five (5) from second year class and third year class to make up the total of one hundred students. Age range-range in itself consider the difference between the highest and lowest value (and in this case, highest age-lowest age). Mean age-mean talks about average of some item and this can be obtained by summing the ages of students under study and dividing it by number of students under study mathematically.

Gender distribution — gender is qualitative in nature hence non-numeric but does not follow any order (no- 
minal scale) therefore, gender entails either a male or female, hence in questionnaires number are assigned to them to make it quantitative.

\subsection{Data Collection Tools and Procedure}

Primary data for the study was collected using questionnaires to solicit their responses from students on the effects of lecturer turnover on their performance whereas secondary data such as records and number of lecturers in various departments was obtained from the Human Resource Department of the Polytechnic. Descriptive statistical tools were employed in the analysis. The responses were collated, analysed and used in identifying trends across all three survey areas. Measures of central tendencies were used to analyse the responses and related them to lecturer turnover and students' performance. The questionnaire is in parts: Section A, consider the demographic aspect of the population. Demographic are quantifiable characteristic of a given population (such as age, gender, education, nationality). Section B considers main aim of the study, and in the case lecturer turnover and students performance". Hence, there are 8 questions in this section. Section A, consider type of respondents under this study and Section B wants to know the depth (perception) of the respondents.

\section{Results and Discussion}

\section{Lecturer Turnover and Students' Performance}

Result from the analysis of the questionnaire indicates that 47 per cent of the students sampled for the study believe that when lecturers resign their motivation to learn are adversely affected. 21 per cent of the students suggested they neither agree nor disagree with the assertion that when lecturers resign their motivation to learn is affected. Some 32 per cent of the respondents were also of the view that lecturer resignation has no effect on their motivation. None of the respondents, however chose strongly agree or strongly disagree (Figure 1). The high number of students who agreed with the assertion is consistent with the literature as per the study by [6], the quality of relationships (trust) between teachers, and between teachers and students, predicts student achievement. Likewise and [7] found "patterned norms" of interaction among colleagues that also predict student achievement. When teachers leave schools, previously held relationships and relational patterns are altered. To the degree that turnover disrupts the formation and maintenance of staff cohesion and community, it may also reduce students' motivation to learn.

Figure 2 shows the results analysis of the question on the effect of lecturer resignation and how students adjust to the new lecturer. The analysis shows that 29 per cent of the students strongly agree with the assertion that

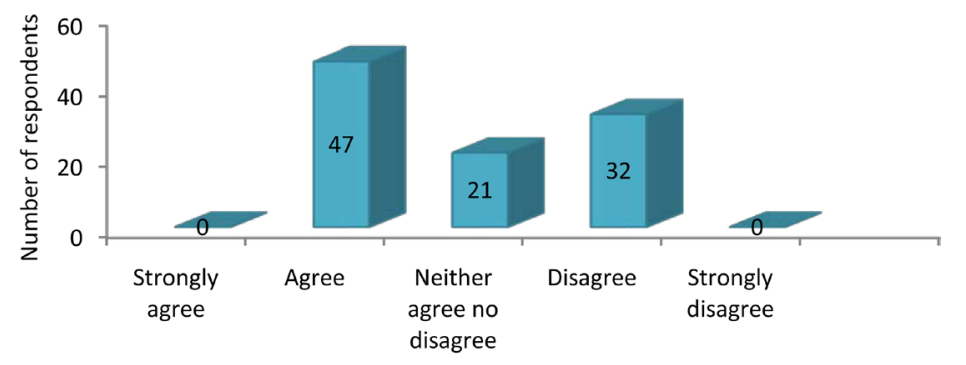

Figure 1. Lecturer resignation and students' motivation.

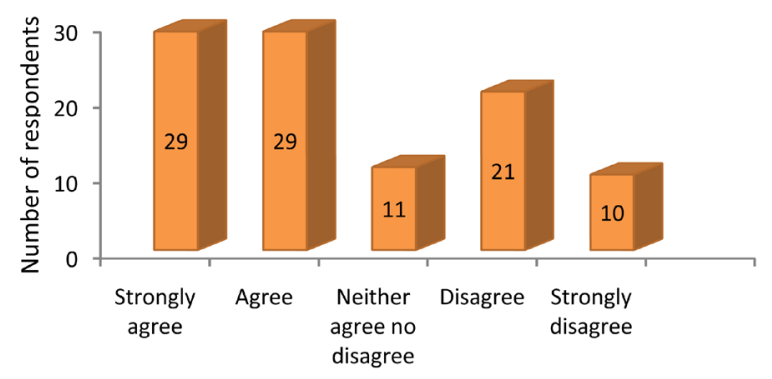

Figure 2. Lecturer resignation and how quick students adjust. 
when lecturers resign and new ones are appointed it takes time for the students to adjust to the new lecturer. Another 29 per cent of the students agree with the statement and 11 per cent of the students stated they neither agree nor disagree. 21 per cent of the students disagreed that when lecturers resign it takes time for them to adjust to the new lecturer appointed and only 10 per cent of the students strongly disagreed with the statement. It is clear from the analysis that majority of the students belief, lecturer resignation adversely affect the performance of students as it becomes very difficult for them to adjust to the new lecturer who takes over. This is in conformity with the findings of [8] who found that when lecturers resign in the middle of the semester it reduces the performance of students as they are unable to adjust to the new lecturer who is appointed.

From Figure 3 the analysis shows that 39 per cent of the respondents strongly agree with the assertion that when lecturers resign the course outline is disrupted. Another 29 per cent of the students also agree with the statement, where as 11 per cent of the students neither agreed nor disagreed and the remaining 21 per cent of the respondents disagreed. However, none of the respondents strongly disagreed with the assertion that when lecturers resign their course outline is disrupted. The analysis clearly shows that 68 per cent of the students believe that lecturer turnover reduces their performance as students because it disrupts the course outline making it difficult for students to follow. [9] in his work found that disruption of programme continuity as a result of a teacher in a higher learning institution decreased students learning and achievements. Xaba in his work also found that student achievement also decreases when there is a shortage of qualified teachers to fill vacant positions, a problem caused at least in part by teacher turnover.

Analysis of the questionnaire revealed that 29 per cent of the students strongly agreed that when lecturers resign and new lecturers are appointed it takes time for the new lecturers to adjust to the system. 32 per cent of the students agreed with the statement, 9 per cent of the students neither agreed nor disagreed and 10 per cent disagreed. 30 per cent of the students strongly disagreed with the assertion. The implication is that newly appointed lecturers are not as effective as those who leave (Figure 4). As [9] stated in his work, the National Commission on Teaching and America's Future (NCTAF) explained that the cost of recruiting new teachers includes cost to students learning at school that result from having new teachers who have little experience, this Xaba termed the learning curve. [10] confirms the outcome of the analysis in their work as they find newly hired teachers to

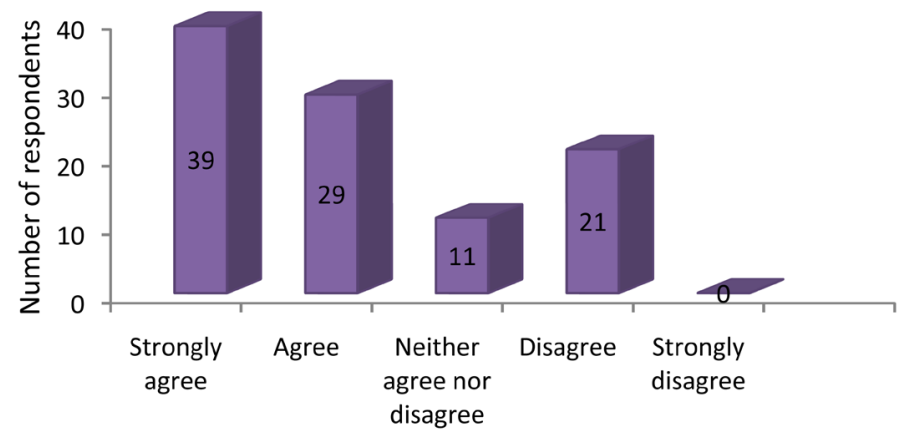

Figure 3. Lecturer resignation and disruption of course outline.

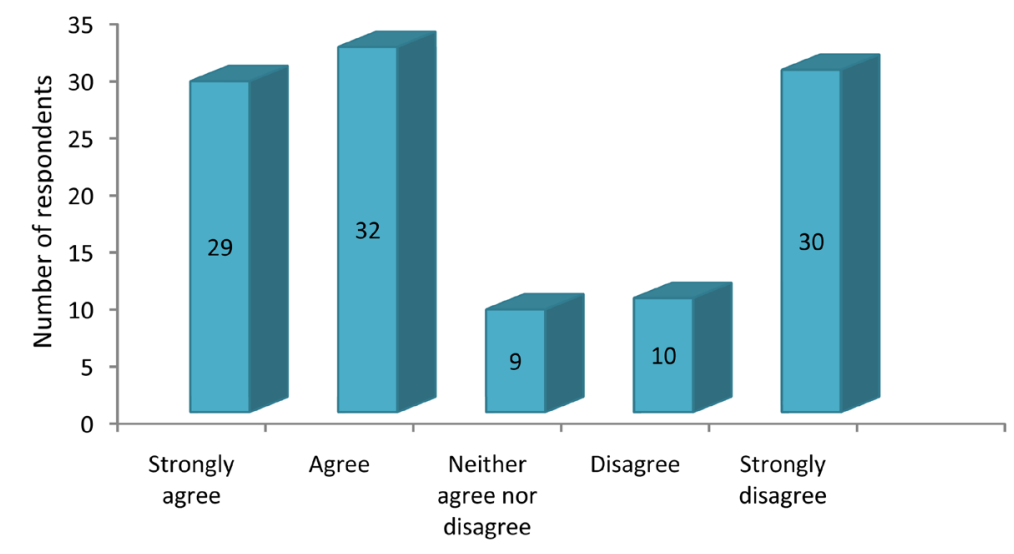

Figure 4. Effect of new lecturer. 
initially lack essential knowledge and skills to implement unfamiliar instructional programme and must be given time to find to acquaint themselves with the requirement of their new position. The initial stage of the appointment therefore retards the progress of the students' performance. It can therefore be concluded that because newly appointed lecturers are unable adjust to the system immediately they are employed, any lecturer turnover that warrants appointing new lecturer is inimical to students' performance.

Figure 5 shows students' responses on how lecturer turnover affects students' preparation for examination. The analysis show that 30 per cent of students strongly agree with the assertion that when lecturers resign at the middle of the semester they become confused on what to prepare on for examination. 60 per cent of the students agreed that their preparation towards examination is hindered by the resignation of lecturers at the middle of the semester. None of the students selected neither agree nor disagree. 13 per cent of the students disagreed and 7 per cent strongly disagreed with the statement. From the analysis it is clear that 90 percent of the students are of the view that lecturer turnover affect their preparation for examination and therefore their performance. The analysis therefore concludes that performance of students is adversely affected by lecturer turnover.

[6] in their work suggested that the relationship between the teacher and the students predicts the performance of the student. Figure 6 shows the analysis of the questionnaire in relation to lecturer turnover and its effect on students' interest in the course. From the analysis of the data, 23 per cent of the students strongly agree with the assertion that when a lecturer resigns they lose interest in the course the lecturer handles. 44 per cent of the students agreed and 7 per cent neither agreed nor disagreed. However 19 per cent of the respondents disagreed and 7 percent strongly disagreed. From the analysis 67 per cent of the students are of the view that when lecturer resigns it reduces their interest in the course the lecturer teaches. It can therefore be concluded that resignation of a lecturer reduces the interest the students have in his course.

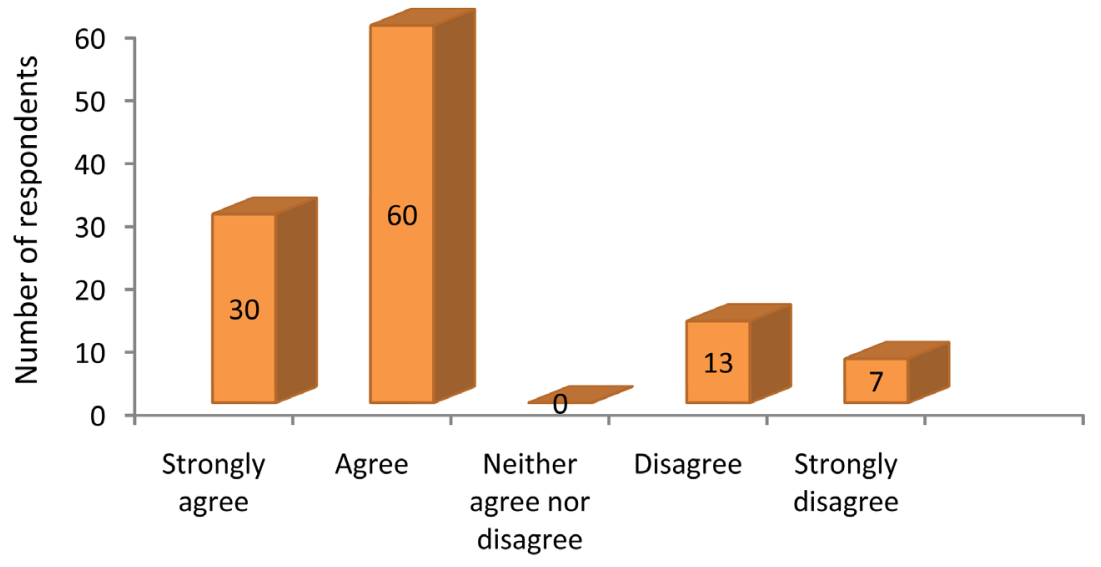

Figure 5. Lecturer resignation and students preparation for examination.

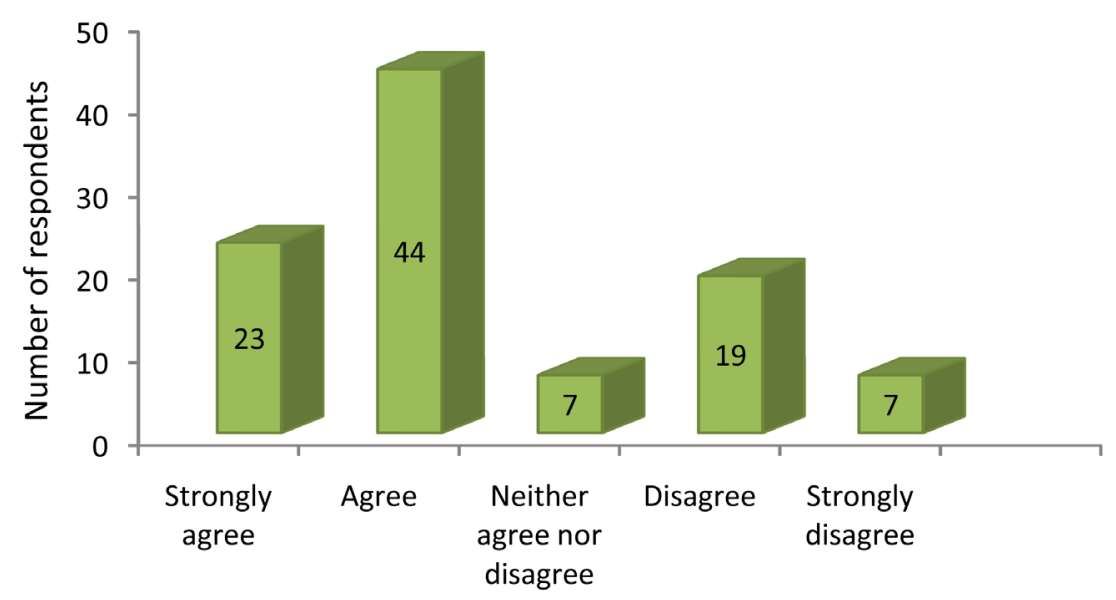

Figure 6. Lecturer resignation and student interest in a course. 
Figure 7 shows the effect of filling a vacancy created by a resigned lecturer with more effective lecturers on students' performance. From the analysis 8 percent of the students strongly agree with the assertion that when lecturers resign and are replaced with more effective ones they are able to perform well and 5 per cent of the students also agree with the assertion. None of the students selected neither agree nor disagree. Surprisingly however, as much as 54 per cent of the students disagreed and another 33 per cent of the students strongly disagreed. From the analysis it can be concluded that 87 per cent of the students are of the view that when a lecturer resigns and is replaced with a more effective lecturer their performance is not improved. The disruptive explanation to teacher turnover effect on students as put forward by [11] clarifies this unusual finding. They explained that teacher turnover disrupts academic work to the extent that even if the teachers who replace the teachers leaving are more competent they are unable to even maintain the standards of students' academic performance. It is therefore concluded that students' performance can improve with turnover when newly appointed lecturers are more effective than those they replace.

From Figure 8 shows that lecturer turnover affects the performance of students. Responses from the students indicate that 53 per cent of the strongly agree that lecturer turnover adversely affect their performance and 32 per cent of the students agreed. 9 per cent of the students selected neither agree nor disagree and 6 per cent disagree. None of the respondents selected strongly disagree. The analysis revealed that 85 per cent of the students are of the view that lecturer turnover adversely affect the performance of students whereas only 6 per cent of the students disagree with the assertion. Generally the performance students fall as with increase in turnover.

\section{Conclusions}

It can also be concluded from the study that lecturer turnover has the adverse effect on the performance of students. Students' morale and motivation to learn fall with lecturer turnover as well as adversely affecting their preparation towards examination especially when lecturers resign in the middle of the semester.

It is clear from the study that lecturer turnover adversely affects performance of students; however, if the exiting lecturers are replaced with more efficient lecturers the performance of the students is likely to improve. It is

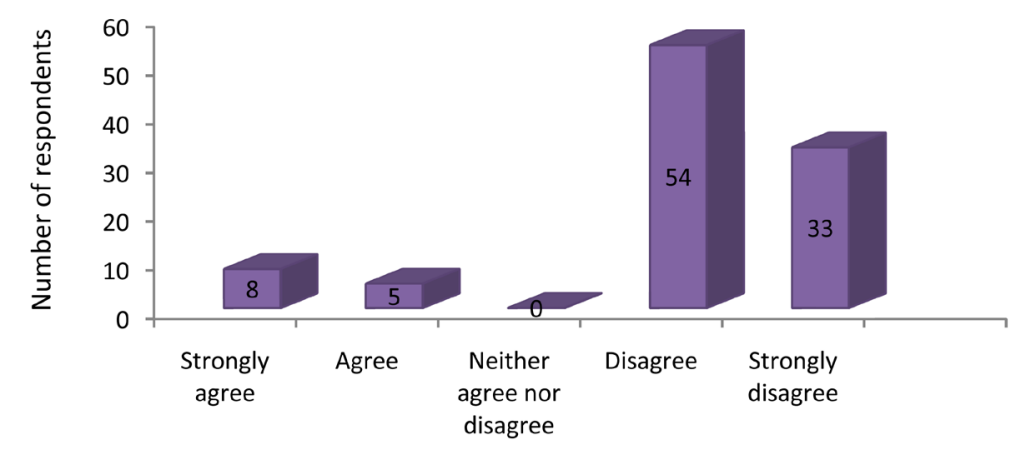

Figure 7. Replacement of resigned lecturer with more effective lecturer and students’ performance.

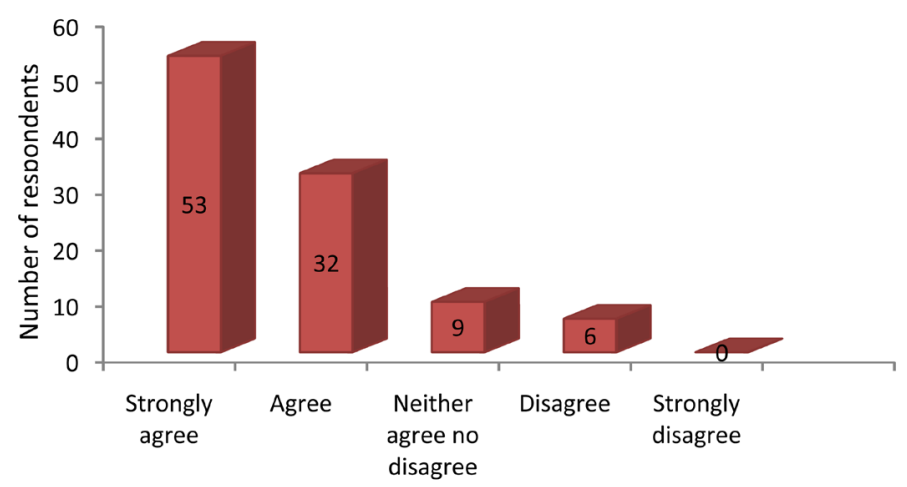

Figure 8. Lecturer resignation and performance of students. 
therefore recommended that to effectively deal with turnover of lecturers when they occur, educational institutions must always find very efficient lecturers as replacement so the performance of the students is not adversely affected.

\section{References}

[1] Stovel, M. and Bontis, N. (2002) Voluntary Turnover: Knowledge Management Friend or Foe? DeGroote School of Business, McMaster University, Hamilton.

[2] Hall, D.T. (2002) Careers in and out of Organisations. Sage Publications, Thousand Oaks.

[3] Samuel, M.O. and Chipunza, C. (2009) Employee Retention and Turnover: Using Motivational Variables as a Panacea. African Journal of Business Management, 3, 410-415.

[4] Stovel, M. and Bontis, N. (2002) Voluntary Turnover: Knowledge Management-Friend or Foe? Journal of Intellectual Capital, 3, 303-322. http://dx.doi.org/10.1108/14691930210435633

[5] Dalton, D.R. and Todor, W.D. (1979) Turnover Turned over: An Expanded and Positive Perspective. Academy of Management Review, 4, 225-235.

[6] Bryk, A.S. and Schneider, B. (2002) Trust in Schools: A Core Resource for Improvement. Russell Sage Foundation, New York.

[7] Little, J.W. (1982) Norms of Collegiality and Experimentation: Workplace Conditions of School Success. American Educational Research Journal, 19, 325-340. http://dx.doi.org/10.3102/00028312019003325

[8] Gillespie, N.A., Walsh, M., Winefield, A.H., Dua, J. and Stough, C. (2001) Occupational Stress in Universities: Staff Perceptions of the Causes, Consequences and Moderators of Stress. Work \& Stress, 15, 53-72. http://dx.doi.org/10.1080/02678370117944

[9] Xaba, M.I. (2003) Managing Teacher Turnover. South African Journal of Education, 23, 287-291.

[10] Abelson, M.A. and Baysinger, B.D. (1984) Optimal and Dysfunctional Turnover: Toward an Organizational Level Model. The Academy of Management Review, 9, 331-341.

[11] Hanushek, E. and Rivkin, S. (2010) Constrained Job Matching: Does Teacher Job Search Harm Disadvantaged Urban Schools? Working Paper No. 15816. National Bureau of Economic Research, Cambridge. 